\title{
ФОРМИ ТА МЕТОДИ ЗАОХОЧЕННЯ КЕРІВНИКІВ ЗАКЛАДІВ ДОШКІЛЬНОЇ ОСВІТИ ДО ПРОФЕСІЙНОГО ЗРОСТАННЯ
}

\section{Тарарак Н. $Г$.}

доктор педагогічних наук, професор, завідувач кафедри теорії, технологій

і методик дошкільної освіти, Харківський національний педагогічний

університет імені Г. С. Сковороди, м. Харків, Україна

У статті проаналізовано провідні форми та методи заохочення завідувачів закладів дошкільної освіти до професійного зростання. Установлено, що до основних видів заохочення керівників ЗДО належать: моральні (грамоти, подяка, занесення до «Книги пошани» та Галереї пошани й ін.); матеріальні (премії, путівки, цінні подарунки тошьо); посадові та професійні заохочення.

Ключові слова: заклад дошкільної освіти, керівник закладу, форми, методи, стимулювання діяльності.

The main forms and methods of encouraging heads of preschool educational institutions for professional growth are analyzed in the article. It is determined that the main types of encouragement of heads of preschool educational institutions are: moral encouragements (diplomas, letters of thanks, entry into "The Book of Honor", Gallery of Honor etc.), material incentives (rewards, trips, valuable gifts etc.), official and professional incentives.

Key words: preschool educational institution, head of institution, forms, methods, stimulation of activity.

Аналіз науково-педагогічних матеріалів дозволяє визначити суть поняття «заохочення». Під даним терміном науковці розуміють методи винагороди за вагомий внесок та значущі досягнення працівників у професійній діяльності, які визначаються чинним законодавством та надаються з метою заохочення працівника до досягнення кращих трудових результатів.

Звернемо увагу на те, що заохочення і нагороди за вагомі досягнення у праці доводяться до відома трудового колективу і заносяться до трудової книжки [3].

Вивчення та узагальнення законодавчих актів дозволяє визначити основні форми та методи заохочення керівників закладів дошкільної освіти до професійного вдосконалення, а саме: премії, котрі передба- 
Розділ III. Історичні та порівняльні аспекти в теорії і практиці духовно-інтелектуального виховання й навчання чені в положенні про преміювання даного працівника; спеціальні премії, що встановлені при досягненні особливих результатів; компенсаційні виплати і відповідні доплати при досягненні пенсійного віку; компенсаційні виплати при звільненні керівника 3 поважних причин; надання пільг і кредиту на будівництво або придбання житлових будинків; надання службового транспорту; видача путівок до санаторіїв та будинків відпочинку; поліпшення житлових умов керівників ЗДО; надання більш кваліфікованої роботи або переміщення на вищу посаду тощо.

Дієвість застосування заохочень, як слушно зазначає Р. Сардінов, залежить від певних чинників, як-от: використання роботодавцем заохочення, котре є бажаним для конкретного працівника; неприпустимість щодо масового використання заохочень; чітке визначення критеріїв щодо їх застосування [4, с. 645].

Вивчення та узагальнення науково-педагогічних матеріалів та діяльності закладів дошкільної освіти дозволяє стверджувати, що до провідних видів заохочення керівників зазначених закладів належать: оголошення подяки завідувачу закладом дошкільної освіти; видача премії; вручення цінних подарунків; відзначення керівника Почесною грамотою; занесення його ім’я до Книги пошани та на Дошку пошани.

Доцільно також вернути увагу на те, що у КЗпП України [2] наголошено, що за особливі трудові досягнення керівники закладів дошкільної освіти можуть бути нагороджені орденами, медалями, нагрудними значками і їх також можуть представити до відповідних почесних звань та звання кращого фахівця за вказаною професією. Особливими трудовими заслугами вважається трудова активність працівника, що своїм результатом має вагоме значення не тільки для підприємства, установи, організації, де працює робітник, а й для держави взагалі.

Керівники закладів дошкільної освіти можуть бути представлені до нагородження такими почесними званнями, як «Заслужений працівник народної освіти України» та «Заслужений вчитель України».

Також варто зазначити, що на сьогоднішній день в Україні існують державні нагороди в галузі освіти, якими відзначаються і керівники галузі дошкільної освіти. Це:

- Державна премія України в галузі освіти (нагорода, якою відзначаються фахівці за значущі досягнення в галузі освіти); 
- Заслужений працівник освіти України (почесне звання, котре присвоюється організаторам освіти за вагомі досягнення в розвитку освіти, у власній професійній діяльності);

- Народний вчитель України (почесне звання, що надається Президентом України, й присвоюється: вчителям, викладачам та іншим педагогічним працівникам за вагомі досягнення, які сприяли істотному зростанню інтелектуального, культурного, духовно-морального потенціалу українського суспільства та здобули широке громадське визнання);

- Заслужений вчитель України (почесне звання, котре надається Президентом України педагогічним працівникам за досягнення вагомих успіхів у навчанні та вихованні підростаючого покоління).

Достатньо поширеною серед керівників закладів дошкільної освіти є практика вручення нагород Президента України працівникам, які відзначились особливими трудовими заслугами, що мають загальнодержавне значення. До таких відзнак належить почесне звання «Герой України» з врученням ордена «Золота Зірка» і ордена Держави [5].

Варто звернути увагу на те, що у чинному трудовому законодавстві України для керівників ЗДО передбачено такі заохочення, як: за успіхи в роботі; за особливі трудові заслуги [2].

Також заохочення поділяють:

- за способами впливу на працівників: на моральні (подяка, вручення грамоти, занесення працівника до книги пошани та на дошку пошани та ін.); матеріальні (грошова премія, цінний подарунок);

- за сферою дії на: загальні (застосовуються для всіх працівників) та спеціальні (стосуються для певних категорій працівників);

- за порядком оформлення і закріплення у правових актах на: правові (регламентовані правовими нормами і вносяться до трудової книжки) та не правові (відзначення працівника в особистій бесіді або просування його по службі);

- $з$ огляду на кратність використання методу заохочення на: одноразового застосування (присвоєння почесного звання), багаторазового застосування (нагородження подарунками) та постійні (премія);

- залежно від інтенсивності впливу стимулювання на задоволення потреб працівника на: короткочасні (видача преміі), періодичні (надання пільг та переваг) та тривалі (присвоєння почесного звання). 
Розділ III. Історичні та порівняльні аспекти в теорії і практиці духовно-інтелектуального виховання й навчання

С. Запара відокремлює такі види заохочень із метою формування ефективної дисципліни праці:

- матеріальне стимулювання індивідуального й колективного характеру (надання житла або кредиту для його придбання, підвищення заробітної платні, преміювання, нагородження цінними подарунками, надання санаторно-курортної путівки та ін.);

- покращення умов праці (ремонт та обладнання службового приміщення сучасною технікою, меблями, придбання літератури та ін.);

- морально-професійне стимулювання працівників (забезпечення комфортних умов діяльності, надання творчих відпусток, відзначення грамотою за вагомі успіхи в роботі та ін.) [1, с. $282-283$ ].

Вивчення та узагальнення науково-педагогічних джерел та досвіду діяльності закладів дошкільної освіти дозволяє визначити основні види заохочення, що застосовуються до керівників ЗДО, а саме:

- моральні заохочення (нагородження грамотою, оголошення подяки, занесення до «Книги пошани» та Галереї пошани, відзначення на різноманітних нарадах; інформація в педагогічних журналах та газетах, присвоєння почесного звання «Людина року» в галузі освіти);

- матеріальні заохочення (преміювання керівників за результатами конкурсів, відкритих занять, креативність, суттєвий внесок у створенні іміджу закладу дошкільної освіти, за перемогу в конкурсі «Вихователь року» та ін., виділення оздоровчих путівок, надання додаткових днів відпочинку, нагородження цінними подарунками, преміювання);

- посадові заохочення (залучення до розробки важливих проєктів, включення керівника до складу атестаційної комісії);

- професійні заохочення (відрядження на конференції, семінари, наради, курси з перепідготовки, організація виставок з актуальних питань освіти; представлення на участь у конкурсі «Вихователь року», «Нове ім'я» та ін., надання дозволу на розробку авторських програм, проведення показових відкритих занять, вивчення й поширення передового педагогічного досвіду ЗДО та керівника).

Наголосимо, що для ефективного стимулювання діяльності керівників закладів дошкільної освіти потрібне комплексне використання зазначених вище видів заохочення. 


\section{Список використаних джерел:}

1. Запара С. Підвищення ефективності правового регулювання дисципліни праці. Проблеми державотворення і захисту прав людини в Україна : Матеріали XII регіональної науково-практичної конференції (9-10 лютого 2006 р.). Львів, 2006. С. 282-283.

2. Кодекс законів про працю України. Режим доступу : http://hrliga.com/ index.php? module $=$ norm_base \&op $=$ view\&id $=94$.

3. Радник. Український юридичний портал. Ст. 143 «Заохочення за успіхи в роботі». Режим доступу : http://radnuk.info/komentar/kzpp/347glava10/5090--143-----.html

4. Сардінов Р. Заохочення за національним законодавством. Форум права. 2012. № 3. C. 642-646.

5. Чефранов А. Заохочення працівників як метод управління персоналом. Довідник кадровика. Режим доступу : http://hrliga.com/index.php?module $=$ profession $\&$ op $=$ view $\&$ id $=750$. 